\title{
Correlation of serum levels of complement C4a desArg with pathologically estimated severity of glomerular lesions and mesangial hypercellularity scores in patients with IgA nephropathy
}

\author{
ATSUSHI SOGABE ${ }^{1,2}$, HIROFUMI UTO ${ }^{1}$, SHUJI KANMURA ${ }^{1}$, TSUYOSHI NOSAKI ${ }^{1,2}$, MIKI OYAMADA ${ }^{1}$, \\ KOKI TOKUNAGA $^{1}$, CHIKA NISHIDA ${ }^{1}$, MAYUMI FUKUMOTO ${ }^{1}$, MANEI OKU ${ }^{1}$, KIICHIRO NISHIMOTO ${ }^{1}$, \\ SHOZO TAKENOUCHI ${ }^{1}$, AKIO IDO ${ }^{1}$, YUKO SHIMADA ${ }^{3}$ and HIROHITO TSUBOUCHI ${ }^{1}$ \\ ${ }^{1}$ Digestive and Lifestyle Diseases, Department of Human and Environmental Sciences, Kagoshima University Graduate \\ School of Medical and Dental Sciences, Kagoshima 890-8544; ${ }^{2}$ Department of Internal Medicine, Nanpuh Hospital, \\ Kagoshima 892-8512; ${ }^{3}$ Miyazaki Industrial Support Foundation, Sadowara, Miyazaki 880-0303, Japan
}

Received December 27, 2012; Accepted March 12, 2013

DOI: $10.3892 /$ ijmm.2013.1390

\begin{abstract}
The aim of the present study was to explore serum biomarkers for the pathology of IgA nephropathy using serum proteomics. The subjects were 57 patients with $\operatorname{IgA}$ nephropathy who were divided into two groups (group 1, $\mathrm{n}=25$; group 2, n=32) and 14 healthy controls. Serum protein profiles were analyzed using the ProteinChip surface-enhanced laser desorption ionization (SELDI) system. Associations between signal intensities of proteins and histological findings in patients with IgA nephropathy were studied in group 1. Serum levels of a candidate biomarker protein (complement component $\mathrm{C} 4 \mathrm{a}$ desArg) for IgA nephropathy were determined by enzyme linked-immunosorbent assay (ELISA) in group 2 and the relationships of these levels with histological findings were evaluated. There were significant differences in 93 protein signals between patients in group 1 and controls. Among these signals, 3 proteins at 8592,8757 and $8806 \mathrm{~m} / \mathrm{z}$ were significantly correlated with the severity of glomerular lesions. The protein at $8592 \mathrm{~m} / \mathrm{z}$ was identified as C4a desArg and the signal intensity of $8592 \mathrm{~m} / \mathrm{z}$ was strongly correlated with serum C4a levels, including C4a desArg, determined by ELISA. In addition, the serum levels of $\mathrm{C} 4 \mathrm{a}$ (mainly $\mathrm{C} 4 \mathrm{a}$ desArg) were significantly higher in patients in group 2 compared to controls and were correlated with the severity of glomerular lesions and with mesangial hypercellularity scores. In conclusion, the serum
\end{abstract}

Correspondence to: Dr Hirofumi Uto, Digestive and Lifestyle Diseases, Department of Human and Environmental Sciences, Kagoshima University Graduate School of Medical and Dental Sciences, 8-35-1 Sakuragaoka, Kagoshima 890-8544, Japan

E-mail: hirouto@m2.kufm.kagoshima-u.ac.jp

Key words: IgA nephropathy, complement C4a, C4a desArg, surface-enhanced laser desorption ionization, proteomics levels of complement $\mathrm{C} 4 \mathrm{a}$ desArg are significantly higher in patients with $\operatorname{Ig} \mathrm{A}$ nephropathy compared to healthy controls and are significantly correlated with the severity of glomerular lesions and mesangial hypercellularity scores. Thus, serum C4a desArg is a potential biomarker for the severity of histological findings in patients with $\operatorname{Ig} \mathrm{A}$ nephropathy.

\section{Introduction}

$\operatorname{Ig}$ A nephropathy is the most common type of primary glomerulonephritis (1). Renal biopsy is required for definite diagnosis of primary glomerulonephritis and $\operatorname{Ig} \mathrm{A}$ nephropathy accounts for $40 \%$ of cases detected using this approach in East Asia and 20\% in Europe. In Japan, 47\% of cases of primary glomerulonephritis are diagnosed as Ig A nephropathy. In addition, $20-30 \%$ of patients with IgA nephropathy progress to end-stage renal disease (ESRD) within 20 years after onset $(2,3)$ and require hemodialysis or renal transplantation.

The pathology of IgA nephropathy is not fully understood, but involves marked mesangial IgA deposits that are often associated with complement component deposits. Furthermore, recurrence of mesangial IgA deposits is seen in approximately $50 \%$ of $\operatorname{IgA}$ nephropathy patients undergoing renal transplantation (4), while these deposits disappear in most patients without IgA nephropathy after renal transplantation from a patient with IgA nephropathy (5,6). In addition, patients with IgA nephropathy often develop gross hematuria following upper respiratory infection, and tonsil stimulation by an ultra short wave may cause deteriorated urinary findings at $3 \mathrm{~h}$ after the mechanical stimulation $(7,8)$. These findings suggest that extrarenal factors and humoral factors are involved in IgA nephropathy.

Since the pathophysiology of IgA nephropathy is unclear, most current treatments aim to reduce immune reactions and inflammation in glomeruli and tubulointerstitium, which result in renal fibrosis. Corticosteroid-induced immune regulation delays progression to ESRD (9), but is only recom- 
mended for patients with increased pathological activity due to possible adverse reactions (10). The Oxford classification of IgA nephropathy was proposed in July 2009 as standard criteria for evaluation of the pathological activity of IgA nephropathy. The pathological findings are related to the clinical features (11-13). Therefore, histological evaluation in patients with IgA nephropathy is required. However, multiple renal biopsies performed for pathological evaluation may cause severe tissue damage and complications. Thus, it would be of value to find a clinically useful biomarker that is correlated with pathological findings in IgA nephropathy.

Biomarkers for various diseases have recently been detected by mass spectrometry (14). Mass spectrometry is generally limited for quantitative analysis, but a semiquantitative assessment can be achieved using the ProteinChip surface-enhanced laser desorption ionization (SELDI) system (15). In this study, we used this system to explore the serum biomarkers which correlate with the pathological activity evaluated histologically in accordance with the Oxford classification in patients with IgA nephropathy.

\section{Materials and methods}

Clinical characteristics in patients with IgA nephropathy. The first group of subjects (group 1) consisted of 25 patients with IgA nephropathy confirmed by renal biopsy from 2006 to 2007 and 14 healthy controls without renal dysfunction used as controls. To verify the utility of serum biomarkers identified in group 1, serum biomarker candidates were determined by enzyme linked-immunosorbent assay (ELISA) in serum from 32 patients with IgA nephropathy (group 2) diagnosed by renal biopsy from 2008 to 2011 (Table I). The backgrounds of the patients and controls were the same, except for urinary protein excretion and age (Table I). Patients with eGFR $<30 \mathrm{ml} / \mathrm{min}$, patients who did not provide appropriate serum at the time of diagnosis, and those with $<10$ glomeruli in a renal biopsy specimen were excluded in each group. The study was approved by the Ethics Committee of Kagoshima University Hospital and Nanpuh Hospital. Written informed consent was obtained from all subjects.

Pathological evaluation. Renal tissues obtained by needle biopsy under ultrasound guidance were evaluated by light microscopy, immunofluorescence microscopy and electron microscopy. Subjects diagnosed with nephritis without IgA nephropathy, such as nephritis related to hepatic dysfunction, lupus nephritis, and poststreptococcal glomerulonephritis, based on clinical course and pathological characteristics were excluded from the study. Subjects with dominant IgA deposits found in the mesangial region by immunofluorescence microscopy and with mesangial proliferative glomerulonephritis confirmed by light microscopy were diagnosed with IgA nephropathy.

Paraffin-embedded specimens were stained with hematoxylin and eosin, periodic acid-Schiff reaction, Masson's trichrome, and periodic acid silver-methenamine, and were evaluated according to the Oxford classification of $\operatorname{Ig} \mathrm{A}$ nephropathy $(12,13)$

Glomerular lesions were evaluated as follows; for mesangial proliferation, all glomeruli without global sclerosis were classified as normal, mild, moderate and severe based on $<4$, 4-5, 6-7 and $\geq 8$ mesangial cells/mesangial area, respectively. The mesangial hypercellularity score was calculated as the mean number of glomeruli for scoring mesangial proliferation (normal, 0 ; mild, 1; moderate, 2; severe, 3). Active glomerular lesions were defined as glomeruli with a cellular crescent, fibrocellular crescent, or endocapillary proliferation. The severity of glomerular lesions was defined as the ratio of active glomerular lesions relative to the total number of glomeruli. Chronic lesions of glomeruli were defined based on the number of glomeruli with global sclerosis, segmental sclerosis, or a fibrous crescent. The severity of chronic lesions was defined as the ratio of chronic lesions relative to the total number of glomeruli.

ProteinChip SELDI system. A comprehensive protein analysis using the ProteinChip SELDI system was performed as previously described $(16,17)$ under the following conditions, in which several protein signals can be obtained in a stable manner. Native serum was applied to a hydrophobic cationexchange chip (CM10, Bio-Rad Laboratories, Hercules, CA, USA). Sinapinic acid was used as the matrix and $50 \mathrm{mM}$ sodium acetate ( $\mathrm{pH} 4.5$ ) as the binding/washing buffer. Protein signal intensities from 2,000 to $11,000 \mathrm{~m} / \mathrm{z}$ were compared between the patient group 1 and control groups.

Binding/washing buffers of $\mathrm{pH}$ 5.0-11.0 were prepared in increments of $\mathrm{pH} 1.0$ for use in experiments to predict the isoelectric point of the target protein. These buffers were sodium acetate ( $\mathrm{pH} 5.0)$, phosphate ( $\mathrm{pH} 6.0$ and 7.0), Tris- $\mathrm{HCl}$ (pH 8.0 and 9.0), and sodium carbonate (pH 10.0 and 11.0). Each was used to wash 7 spots on the CM10 chip and then the spectrum was obtained by time-of-flight mass spectrometry. The $\mathrm{pH}$ at which the peak disappeared was estimated as the approximate pI value. Peptides were predicted from the pI value and the molecular weight based on a published database (Tagldent: http://web.expasy.org/tagident/).

Crude fractionation, demineralization and concentration of serum samples. Crude fractionation of serum samples was performed using a weak cation-exchange absorbent column (HiTrap CM FF 5 ml column, GE Healthcare Bio-Sciences $\mathrm{KK}$, Tokyo, Japan) to remove proteins that inhibit reactions between biomarker candidate proteins and specific antibodies. Serum containing biomarker candidates was diluted 5 times with phosphate buffer ( $\mathrm{pH}$ 7.5) and applied to the column. Proteins and peptides bound to the column were then eluted using $0.5 \mathrm{M} \mathrm{NaCl}$ in phosphate buffer. The eluent was desalted and concentrated using an ultrafiltration column (Vivaspin 500 Polyethersulfone 5,000 MWCO, Sartorius Stedim Biotech, Goettingen, Germany) and an ultrafilter (5,000 MWCO). Protein levels were determined by Bradford's method (Quick Start Protein Assay, Bio-Rad Laboratories).

Immunoprecipitation. A combination of $50 \%$ protein A (Protein A Sepharose CL-4B, GE Healthcare) suspension and 1:5 diluted rabbit anti-human $\mathrm{C} 4 \mathrm{a}$ polyclonal antibody (\#A206, Complement Technology, Inc., Tyler, TX, USA) was incubated with shaking overnight at $4^{\circ} \mathrm{C}$. The rabbit antihuman $\mathrm{C} 4 \mathrm{a}$ antibody-bound protein $\mathrm{A}$ and serum samples containing biomarker candidate proteins were mixed, incu- 
Table I. Characteristics of patients with IgA nephropathy and healthy controls.

\begin{tabular}{|c|c|c|c|c|c|c|}
\hline \multirow[b]{2}{*}{ Characteristics } & \multirow{2}{*}{$\begin{array}{l}\text { Healthy } \\
\text { controls } \\
(n=14)\end{array}$} & \multirow{2}{*}{$\begin{array}{l}\text { Patient } \\
\text { group } 1 \\
(n=25)\end{array}$} & \multirow{2}{*}{$\begin{array}{l}\text { Patient } \\
\text { group } 2 \\
(n=32)\end{array}$} & \multicolumn{3}{|c|}{ P-value ${ }^{a}$} \\
\hline & & & & C vs. G1 & C vs. G2 & G1 vs. G2 \\
\hline Gender (M/F) & $5 / 9$ & $11 / 14$ & $16 / 16$ & 0.614 & 0.371 & 0.652 \\
\hline Age & $34.4 \pm 6.9$ & $34.1 \pm 13.2$ & $28.8 \pm 10.8$ & 0.792 & 0.035 & 0.110 \\
\hline UPE (g/g Cre) & ND & $0.80 \pm 0.72$ & $0.49 \pm 0.55$ & ND & ND & 0.081 \\
\hline Serum Cre $(\mathrm{mg} / \mathrm{dl})$ & $0.76 \pm 0.17$ & $0.83 \pm 0.27$ & $0.74 \pm 0.15$ & 0.682 & 0.830 & 0.505 \\
\hline eGFR (ml/min) & $81.9 \pm 15.8$ & $82.0 \pm 26.2$ & $95.8 \pm 29.1$ & 0.942 & 0.133 & 0.085 \\
\hline Serum IgA $(\mathrm{mg} / \mathrm{dl})$ & $261.1 \pm 68.5$ & $327.8 \pm 115.4$ & $330.3 \pm 150.2$ & 0.083 & 0.126 & 0.676 \\
\hline Serum C3 (mg/dl) & $93.8 \pm 11.9$ & $103.3 \pm 17.2$ & $99.2 \pm 15.3$ & 0.098 & 0.252 & 0.426 \\
\hline Serum C4 (mg/dl) & $21.2 \pm 4.0$ & $25.4 \pm 7.4$ & $24.2 \pm 5.7$ & 0.119 & 0.108 & 0.635 \\
\hline
\end{tabular}

${ }^{a}$ Comparison of data by Fisher's exact test or Mann-Whitney U test, as appropriate. ND, not done; UPE, urinary protein excretion; Cre, creatinine; eGFR, estimated glomerular filtration rate; $\mathrm{C}$, control; G1, group 1; G2, group 2.

bated, and then centrifuged to separate supernatant from precipitates of the $\mathrm{C} 4 \mathrm{a}$-anti $\mathrm{C} 4 \mathrm{a}$ antibody-protein $\mathrm{A}$ complex. Normal rabbit IgG (sc-2027, Santa Cruz Biotechnology, Inc., Santa Cruz, CA, USA) was used as a control antibody. The supernatant was divided into two parts; one was diluted with sodium acetate buffer $(\mathrm{pH} 4.5)$ and used for ProteinChip SELDI system, while the other was incubated with sample buffer with $\beta$-mercaptoethanol at $95^{\circ} \mathrm{C}$ and then used in tricine-SDS-PAGE. The collected precipitates were washed with PBS several times and incubated with sample buffer with $\beta$-mercaptoethanol to release $\mathrm{C} 4 \mathrm{a}$ including $\mathrm{C} 4 \mathrm{a}$ desArg from the $\mathrm{C} 4 \mathrm{a}$-anti $\mathrm{C} 4 \mathrm{a}$ antibody-protein $\mathrm{A}$ complex. The resulting mixture was centrifuged to remove protein $\mathrm{A}$ and the remaining supernatant was used for tricine-SDS-PAGE.

Tricine-SDS-PAGE and western blot analysis. Tricine-SDSPAGE was performed as previously described (18), using $0.1 \mathrm{M}$ Tris/ $0.0225 \mathrm{M} \mathrm{HCl}$ and $0.1 \mathrm{M}$ Tris/0.1M Tricine/ $/ 1 \%$ SDS as the anode and cathode buffers, respectively. For the western blotting, the rabbit anti-human C4a antibody (\#A206, Complement Technology, Inc.) was used as the primary antibody and goat anti-rabbit IgG-HRP (sc-2004, Santa Cruz Biotechnology, Inc.) as the secondary antibody for visualization of the target proteins with a chemiluminescent reagent (ECL Plus, GE Healthcare UK Ltd., Buckinghamshire, UK).

Purified C4a desArg using the ProteinChip SELDI system. Purified C4a desArg (\#A107, Complement Technology, Inc.) was prepared as solutions of 1 and $5 \mu \mathrm{g} / \mathrm{ml}$. These solutions were diluted 10 times with sodium acetate buffer ( $\mathrm{pH} 4.5)$ and diluted solutions $(100 \mu \mathrm{l})$ were applied to the ProteinChip SELDI system with the CM10 chip. C4a desArg was also added to serum from healthy controls to give a concentration of $50 \mu \mathrm{g} / \mathrm{ml}$. The mixture was diluted 10 times with PBS and 10 times with sodium acetate buffer ( $\mathrm{pH} 4.5)$ and then diluted solutions (100 $\mu \mathrm{l})$ were applied to the ProteinChip SELDI system.

Determination of serum levels of complement C4a/C4a desArg. The level of serum $\mathrm{C} 4 \mathrm{a}$ including $\mathrm{C} 4 \mathrm{a}$ desArg was
Table II. Representative discriminatory signals and mean values for patients with IgA nephropathy (group 1) and healthy controls.

\begin{tabular}{lcccc}
\hline Number & $\mathrm{m} / \mathrm{z}$ & $\begin{array}{c}\text { Patient } \\
\text { group } 1 \\
(\mathrm{n}=25)\end{array}$ & $\begin{array}{c}\text { Healthy } \\
\text { controls } \\
(\mathrm{n}=14)\end{array}$ & P-value \\
\hline 1 & 3191 & $12.68 \pm 4.68$ & $21.32 \pm 5.11$ & $<0.0001$ \\
2 & 8592 & $7.85 \pm 8.38$ & $2.89 \pm 2.58$ & 0.0008 \\
3 & 4465 & $9.67 \pm 3.20$ & $5.66 \pm 3.00$ & 0.0009 \\
4 & 6005 & $4.08 \pm 1.53$ & $5.53 \pm 1.22$ & 0.0012 \\
5 & 4611 & $3.60 \pm 3.86$ & $1.37 \pm 1.07$ & 0.0013 \\
6 & 6149 & $1.63 \pm 0.85$ & $2.46 \pm 0.78$ & 0.0013 \\
7 & 8924 & $23.96 \pm 9.31$ & $13.22 \pm 8.25$ & 0.0013 \\
8 & 4641 & $15.60 \pm 3.74$ & $12.20 \pm 2.09$ & 0.0014 \\
$:$ & $:$ & $:$ & $:$ & $:$ \\
27 & 8757 & $2.24 \pm 1.00$ & $1.39 \pm 0.74$ & 0.0084 \\
$:$ & $:$ & $:$ & $:$ & $:$ \\
38 & 8806 & $3.18 \pm 1.16$ & $2.34 \pm 0.80$ & 0.0118 \\
$:$ & $:$ & $:$ & $:$ & $:$ \\
93 & 10256 & $4.61 \pm 2.52$ & $7.29 \pm 4.03$ & $<0.050$ \\
\hline & & & & $:$
\end{tabular}

determined using an ELISA kit (Human C4a ELISA kit, BD Biosciences, Franklin Lakes, NJ, USA).

Statistical analysis. Data are expressed as the means \pm standard deviation (SD). Differences in laboratory data and signal intensities obtained by SELDI were evaluated by Mann-Whitney U test. Regression analysis was performed to examine the correlation of continuous variables. A P-value $<0.05$ was considered to indicate a statistically significant 
A

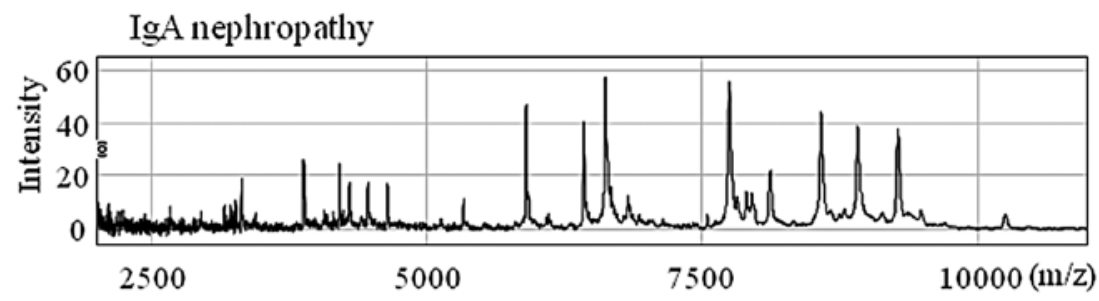

B

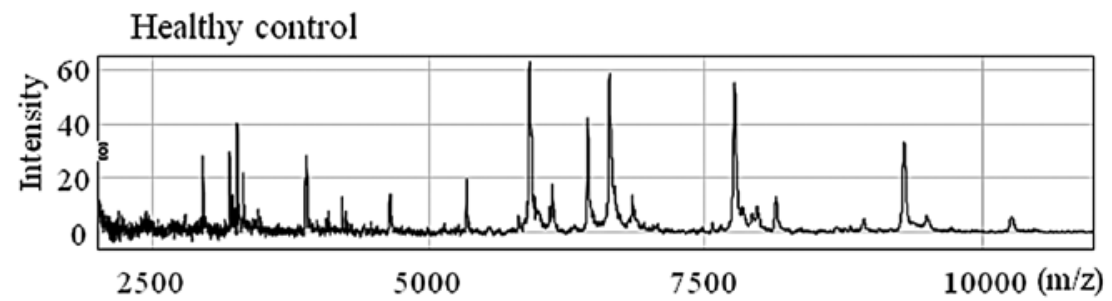

Figure 1. Representative SELDI spectra $(2,000-11,000 \mathrm{~m} / \mathrm{z})$ of serum from patients with IgA nephropathy and healthy controls. (A) IgA nephropathy; (B) healthy controls.

A

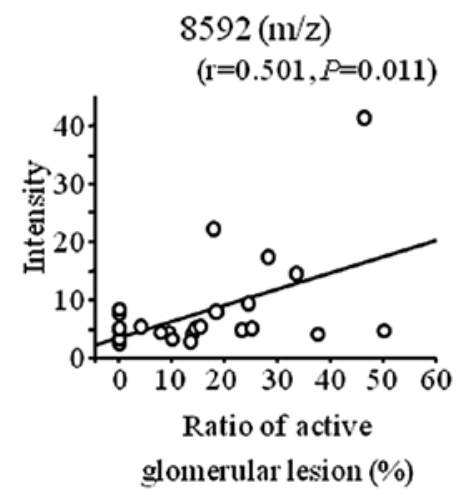

B

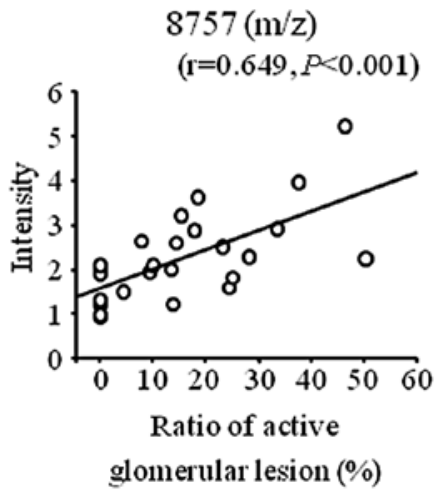

C

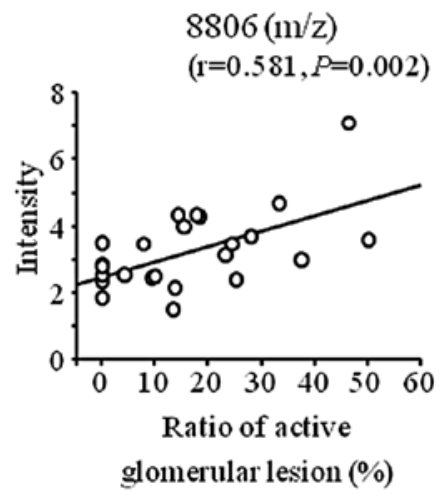

Figure 2. Correlation between three protein peaks and pathological severity estimated by rate of active glomerular lesion. (A) 8592 ; (B) 8757 ; (C) $8806 \mathrm{~m} / \mathrm{z}$.

difference. Analyses were performed with StatView 4.5 software (Abacus Concepts, Berkeley, CA, USA) or ProteinChip Software, version 3.2.1 (Bio-Rad Laboratories).

\section{Results}

Exploration of biomarker candidates in patients with IgA nephropathy. Serum spectra were obtained from 25 patients with $\operatorname{Ig}$ A nephropathy and 14 healthy controls using the ProteinChip SELDI system (Fig. 1). A total of 558 signal clusters were detected from 2,000 to $11,000 \mathrm{~m} / \mathrm{z}$, and 93 of these signals differed significantly between the patients and controls (Table II). Simple regression analysis was performed between the intensity of these 93 signals and the severity of glomerular lesion evaluated histologically, with the goal of finding biomarker candidate proteins correlated with the pathological activity of IgA nephropathy. In this process, 3 signals $(8592,8757,8806 \mathrm{~m} / \mathrm{z})$ were identified as potential biomarkers (Table II, Fig. 2A-C). A protein at $8592 \mathrm{~m} / \mathrm{z}$ was also increased in the patients with IgA nephropathy compared to the controls, with a mean intensity $>5$ in the patients (Table II).
Identification of a biomarker candidate protein $(8592 \mathrm{~m} / \mathrm{z})$. The protein signal at $8592 \mathrm{~m} / \mathrm{z}$ was not detected using the ProteinChip SELDI system (CM10 chip) in serum diluted with buffer at $\mathrm{pH} 10.0$, which suggested that the isoelectric point of the protein at $8592 \mathrm{~m} / \mathrm{z}$ was between $\mathrm{pH} 9.0-10.0$. Based on the Tagldent database of isoelectric point and molecular weight, the signal at $8592 \mathrm{~m} / \mathrm{z}$ was expected an inactivated peptide of $\mathrm{C} 4 \mathrm{a}$ anaphylatoxin (C4a desArg; $8590 \mathrm{Da}, \mathrm{pI}=9.6)$.

The protein signal at $8592 \mathrm{~m} / \mathrm{z}$ detected in serum of patients with IgA nephropathy (Fig. 3A) was not eliminated by immunoprecipitation using the control antibody (Fig. 3B), but disappeared with immunoprecipitation using anti-C4a antibody (Fig. 3C). Western blot analysis confirmed the presence of $\mathrm{C} 4 \mathrm{a}$ or $\mathrm{C} 4 \mathrm{a}$ desArg by the immunoprecipitation assay (Fig. 3D). Purified C4a desArg diluted 10 times with sodium acetate buffer ( $\mathrm{pH} 4.5)$ also gave a signal at $8592 \mathrm{~m} / \mathrm{z}$ using the ProteinChip SELDI system (CM10 chip) and the signal intensity was dependent on the concentration (Fig. 4B and C). Similarly, a signal at $8592 \mathrm{~m} / \mathrm{z}$ appeared when purified C4a desArg was added to serum from healthy controls (Fig. 4E), at the same position as the protein signal in serum from patients 
A

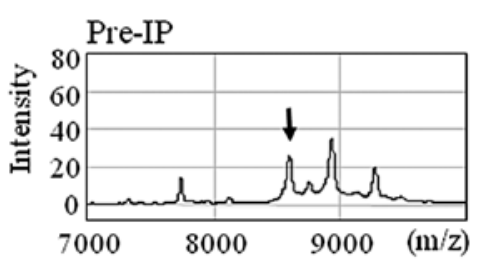

B

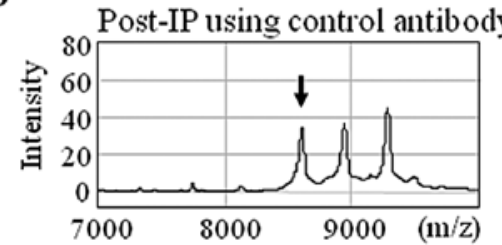

C

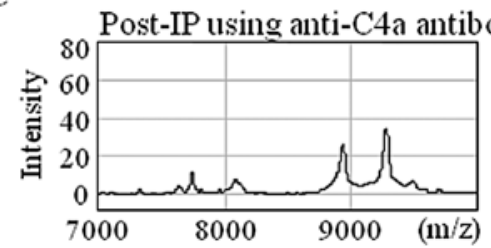

D

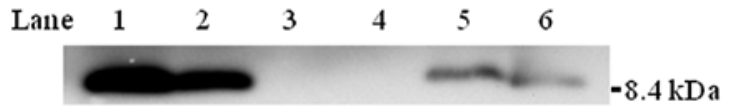

Lane 1, Serum from IgA nephropathy without IP

2 , Sup ernatant after IP using control antibody

3, Supernatant after IPusing anti-C4a antibody

4, Precipitate after IP using control antibody

5 , Precipitate after IP using anti-C4a antibody

6, Positive control (C4a desArg).

Figure 3. Immunoprecipitation (IP) and analysis with the ProteinChip SELDI system or western blotting using anti-C4a antibody. A protein signal at $8592 \mathrm{~m} / \mathrm{z}$ (arrow) was detected in serum from patients with IgA nephropathy prior to IP (A) and following IP using control antibody (B). By contrast, this signal was not detected in serum from patients with IgA nephropathy following treatment of the serum with anti-C4a antibody (C). C4a or C4a desArg was also detected in serum from patients with IgA nephropathy without IP (lane 1) and in supernatant after IP using control antibody (lane 2), but not in supernatant after IP using anti-C4a antibody (lane 3). C4a or C4a desArg was not detected in precipitate after IP using control antibody (lane 4), but was detected in precipitate after IP using anti-C4a antibody (lane 5). A positive control using $\mathrm{C} 4 \mathrm{a}$ desArg and anti-C4a antibody is shown in lane 6.

A

Serum from a patient with IgA nephropathy

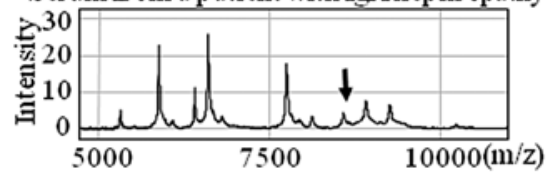

B

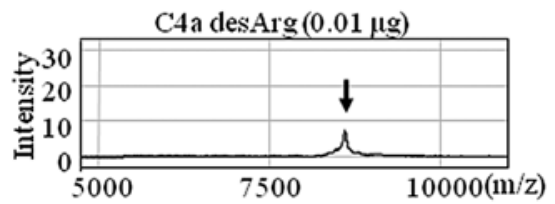

C

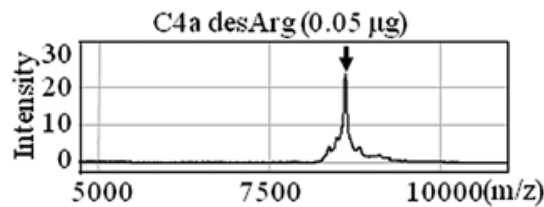

D

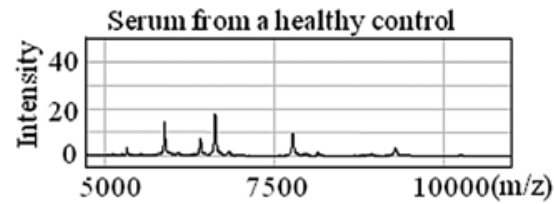

E

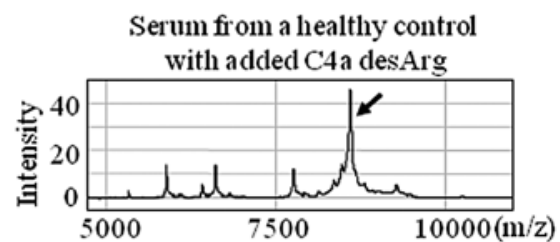

$\mathbf{F}$

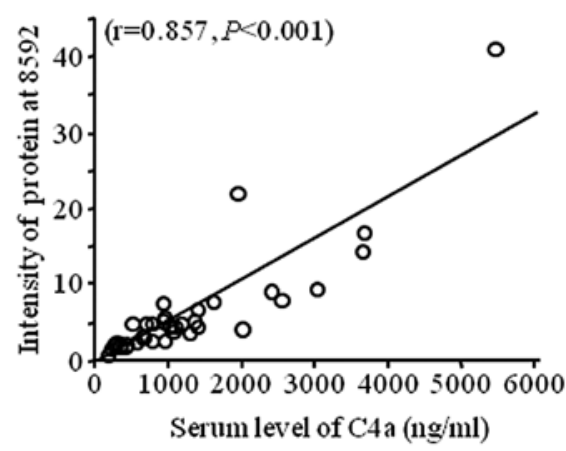

Figure 4. Detection of purified C4a desArg on a SELDI spectrum at $8592 \mathrm{~m} / \mathrm{z}$ and correlation of the signal intensity at $8592 \mathrm{~m} / \mathrm{z}$ with C4a (including C4a desArg) levels determined by ELISA. (A) SELDI spectrum of serum from patients with IgA nephropathy. (B and C) SELDI spectra of phosphate-buffered saline mixed with C4a desArg. (B) $0.01 \mu \mathrm{g}$; (C) $0.05 \mu \mathrm{g}$. (D) SELDI spectrum of serum from healthy controls. (E) SELDI spectrum of serum from healthy controls mixed with C4a desArg $(0.05 \mu \mathrm{g})$. (F) The signal intensity at $8592 \mathrm{~m} / \mathrm{z}$ was strongly correlated with the level of C4a (including C4a desArg) determined by ELISA in patients with IgA nephropathy. Arrows indicate C4a desArg detected at $8592 \mathrm{~m} / \mathrm{z}$ (A, B, C and E). 


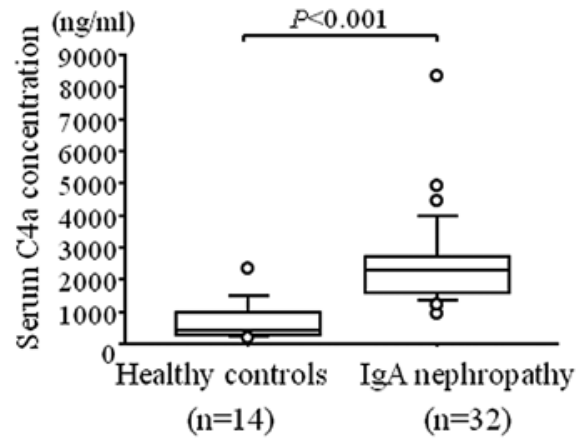

Figure 5. Serum levels of $\mathrm{C} 4 \mathrm{a} / \mathrm{C} 4 \mathrm{a}$ desArg in patients with $\mathrm{IgA}$ nephropathy in group 2 were higher than those in healthy controls.

with IgA nephropathy (Fig. 4A). These results show that the peak at $8592 \mathrm{~m} / \mathrm{z}$ was due to C4a desArg.

In addition, the levels of $\mathrm{C} 4 \mathrm{a}$, including $\mathrm{C} 4 \mathrm{a}$ desArg, determined by ELISA were strongly correlated with the signal intensity at $8592 \mathrm{~m} / \mathrm{z}(\mathrm{r}=0.86, \mathrm{P}<0.001, \mathrm{Fig}$. $4 \mathrm{~F})$. Thus, our results suggest that most $\mathrm{C} 4 \mathrm{a}$ evaluated by ELISA in patients with IgA nephropathy is in the form of inactivated peptide C4a desArg.

Relationship between pathological data and serum $\mathrm{C} 4 \mathrm{a} / \mathrm{C} 4 \mathrm{a}$ desArg in patient group 1. The serum levels of $\mathrm{C} 4 \mathrm{a}$ (mainly C4a desArg) in group 1 determined by ELISA were significantly higher in patients with IgA nephropathy compared to healthy controls $(1564.5 \pm 1129.0$ vs. $708.2 \pm 622.1 \mathrm{ng} / \mathrm{ml}$, $\mathrm{P}=0.002)$. Correlations of the severity of glomerular lesion with the serum levels of $\mathrm{C} 4 \mathrm{a} / \mathrm{C} 4 \mathrm{a}$ desArg and other laboratory data (urinary protein excretion, eGFR, IgA) were also examined in group 1 . The severity was positively correlated with the serum levels of $\mathrm{C} 4 \mathrm{a} / \mathrm{C} 4 \mathrm{a}$ desArg $(\mathrm{r}=0.62, \mathrm{P}<0.001)$ and urinary protein excretion $(\mathrm{r}=0.55, \mathrm{P}=0.005)$. In addition, the mesangial hypercellularity score, which is related to a decrease in renal function (12), was positively correlated with the serum levels of $\mathrm{C} 4 \mathrm{a} / \mathrm{C} 4 \mathrm{a}$ desArg $(\mathrm{r}=0.54, \mathrm{P}=0.005)$. By contrast, the severity of chronic glomerular lesions was not correlated with the serum levels of $\mathrm{C} 4 \mathrm{a} / \mathrm{C} 4 \mathrm{a}$ desArg.

Clinical significance of serum $\mathrm{C} 4 \mathrm{a} / \mathrm{C} 4 \mathrm{a}$ desArg in patient group 2. To confirm the results from patient group 1, the clinical significance of the serum levels of $\mathrm{C} 4 \mathrm{a} / \mathrm{C} 4 \mathrm{a}$ desArg were evaluated in a second group of patients with $\operatorname{IgA}$ nephropathy (group 2). The $\mathrm{C} 4 \mathrm{a} / \mathrm{C} 4 \mathrm{a}$ desArg levels determined by ELISA in this group were also significantly higher than those in healthy controls (Fig. 5, P<0.001). The serum levels of $\mathrm{C} 4 \mathrm{a} / \mathrm{C} 4 \mathrm{a}$ desArg also correlated with the severity of glomerular lesion (Fig. 6A, $\mathrm{P}=0.035)$ and were significantly correlated with mesangial hypercellularity scores (Fig. 6B, $\mathrm{P}=0.014$ ) in group 2.

\section{Discussion}

Three signals $(8592,8757,8806 \mathrm{~m} / \mathrm{z})$ of potential biomarkers related to the severity of glomerular lesions were identified in serum proteomics of patients with IgA nephropathy. The signal at $8592 \mathrm{~m} / \mathrm{z}$ was confirmed to be due to C4a desArg, which was also shown to be positively correlated with mesangial hypercellularity scores in two groups of patients with IgA nephropathy.
A

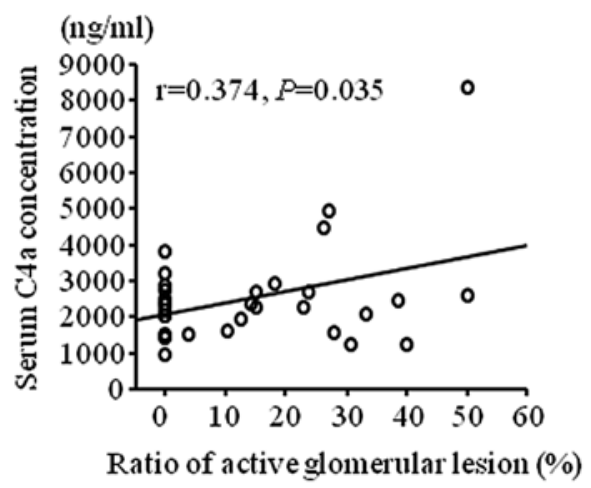

B

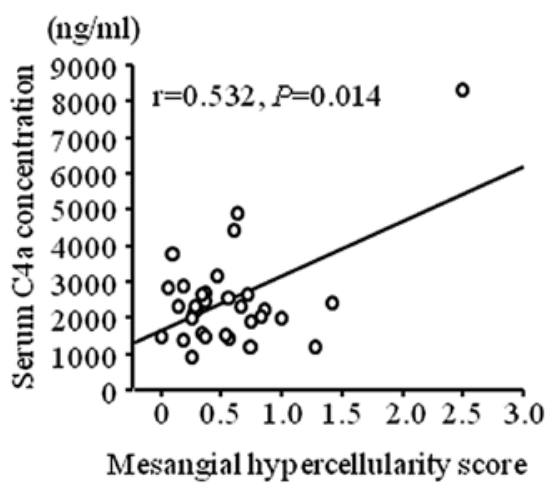

Figure 6. Correlation between serum levels of $\mathrm{C} 4 \mathrm{a} / \mathrm{C} 4 \mathrm{a}$ desArg and the histological findings in $\operatorname{IgA}$ nephropathy patients in group 2. Serum levels of $\mathrm{C} 4 \mathrm{a} / \mathrm{C} 4 \mathrm{a}$ desArg were significantly correlated with the ratio of active glomerular lesions (A) and mesangial hypercellularity scores (B).

$\mathrm{C} 4 \mathrm{a}$ is an anaphylatoxin and strong inflammation-inducing agent derived from complement component $\mathrm{C} 4$. C4a desArg, which has low anaphylatoxin activity, is formed from $\mathrm{C} 4 \mathrm{a}$ by fast cleavage of arginine by carboxypeptidase $\mathrm{N}$ in serum. It is considered that the majority of $\mathrm{C} 4 \mathrm{a}$ in serum is $\mathrm{C} 4 \mathrm{a}$ desArg, and we confirmed a strong correlation between $\mathrm{C} 4 \mathrm{a}$ levels determined by ELISA and the level of C4a desArg detected by SELDI. The complement pathway is activated in patients with IgA nephropathy and, in this study, C4a desArg levels were significantly higher in these patients than in healthy controls. By contrast, there was no significant difference in $\mathrm{C} 4$ levels between the patients and healthy controls. These results suggest that the C4a desArg level can serve as an index of complement activation in IgA nephropathy.

Serum levels of C4a (mainly C4a desArg) determined by ELISA were significantly correlated with pathologically estimated mesangial hypercellularity scores and with the severity of glomerular lesions in both groups of patients with IgA nephropathy. The mesangial hypercellularity score is a measure of mesangial cell proliferation and is likely to be a prognostic factor for renal function and to indicate the severity of glomerular lesions. In proposing the Oxford classification, the working group of the International IgA Nephropathy Network and the Renal Pathology Society suggested that the mesangial hypercellularity score was the most reproducible pathological finding among investigators (13). Therefore, our results suggest that the serum level of complement $\mathrm{C} 4 \mathrm{a}$ 
desArg may serve as a biomarker to estimate the mesangial hypercellularity score, as a prognostic factor, and as an index of the effect of immunoregulatory therapy in patients with IgA nephropathy. A long-term follow-up study is required to confirm these results.

Complement deposition is observed in $\operatorname{Ig} \mathrm{A}$ deposition sites in patients with IgA nephropathy, which suggests that the complement system may be involved in the pathology, and increased plasma levels of the anaphylatoxins C3a and C4a have been reported in these patients (19). However, the mechanism and clinical significance of complement activation in IgA nephropathy is unclear. Activation may occur through an alternative pathway (20), but it has recently been proposed that the lectin pathway is involved in complement activation in IgA nephropathy $(21,22)$. Furthermore, C4d deposition in glomeruli and activation of the lectin pathway influence the prognosis of IgA nephropathy and the severity of renal injury $(23,24)$. The current study also showed that serum $\mathrm{C} 4 \mathrm{a}$ desArg levels were correlated with mesangial hypercellularity scores and the severity of glomerular lesions. Complement components other than $\mathrm{C} 4$ remain to be investigated; however, our study indicates that complement activation by $\mathrm{C} 4$ may be important in $\operatorname{Ig}$ A nephropathy.

Our results indicated a correlation between serum levels of complement C4a (mainly C4a desArg) and histological activity estimated by severity of glomerular lesions and mesangial hypercellularity scores in both groups of patients with IgA nephropathy. By contrast, serum levels of complement $\mathrm{C} 4 \mathrm{a}$ or $\mathrm{C} 4 \mathrm{a}$ desArg were not related to the severity of chronic glomerular lesions. Urinary protein excretion is used as a laboratory test of the severity of renal injury and is strongly influenced by chronic glomerular lesions, which are unlikely to be responsive to anti-inflammatory therapy. By contrast, serum levels of complement $\mathrm{C} 4 \mathrm{a}$ and $\mathrm{C} 4 \mathrm{a}$ desArg are not influenced by urinary protein excretion. The independence of the serum level of $\mathrm{C} 4 \mathrm{a}$ desArg with respect to urinary protein excretion may also make it a useful index of the effect of anti-inflammatory therapy in IgA nephropathy.

One limitation of identification of a complement-related molecule, including an anaphylatoxin such as $\mathrm{C} 4 \mathrm{a}$ desArg, as a biomarker candidate is that complement may be activated even after blood sample collection $(25,26)$. Pfeifer et al showed that $\mathrm{C} 4 \mathrm{a} / \mathrm{C} 4 \mathrm{a}$ desArg levels increased over time in plasma samples from patients with systemic lupus erythematosus stored at $37^{\circ} \mathrm{C}$ without addition of futhan (25). The $\mathrm{C} 4 \mathrm{a} / \mathrm{C} 4 \mathrm{a}$ desArg levels in plasma samples of healthy controls collected in the same manner and stored for $60 \mathrm{~min}$ at $37^{\circ} \mathrm{C}$ were also higher than those measured immediately after collection (26). Thus, the serum levels of complement $\mathrm{C} 4 \mathrm{a} / \mathrm{C} 4 \mathrm{a}$ desArg measured in the current study were likely to be higher than those in blood in vivo. However, the effects ex vivo can be minimized by shortening the time from sample collection to centrifugation and freezing to eliminate sample variability. The measured $\mathrm{C} 4 \mathrm{a}$ desArg levels might reflect complement activation ex vivo as well as that in vivo, but these levels still showed a considerable correlation with the severity of glomerular lesion and mesangial hypercellularity scores in two separate groups of patients with $\operatorname{IgA}$ nephropathy. Therefore, we conclude that the $\mathrm{C} 4 \mathrm{a} / \mathrm{C} 4 \mathrm{a}$ desArg levels in these patients are useful as a surrogate marker of disease severity. Verification of these findings requires measurements in samples with control of complement activation ex vivo. A prospective study is also required to confirm the correlation between serum C4a desArg levels and the pathological activity of $\operatorname{IgA}$ nephropathy.

In conclusion, the serum level of $\mathrm{C} 4 \mathrm{a}$ (mainly $\mathrm{C} 4 \mathrm{a}$ desArg) is significantly higher in patients with $\operatorname{IgA}$ nephropathy compared to healthy controls and is significantly correlated with the severity of glomerular lesions and mesangial hypercellularity scores evaluated histologically using the Oxford classification of $\operatorname{IgA}$ nephropathy. Thus, serum C4a desArg is a potential biomarker for the severity of histological findings in patients with $\operatorname{Ig}$ A nephropathy.

\section{References}

1. Donadio JV and Grande JP: IgA nephropathy. N Engl J Med 347: 738-748, 2002.

2. D'Amico G: Influence of clinical and histological features on actuarial renal survival in adult patients with idiopathic IgA nephropathy, membranous nephropathy, and membranoproliferative glomerulonephritis: survey of the recent literature Am J Kidney Dis 20: 315-323, 1992

3. Alamartine E, Sabatier JC, Guerin C, Berliet JM and Berthoux F: Prognostic factors in mesangial IgA glomerulonephritis: an extensive study with univariate and multivariate analyses. Am J Kidney Dis 18: 12-19, 1991.

4. Odum J, Peh CA, Clarkson AR, et al: Recurrent mesangial IgA nephritis following renal transplantation. Nephrol Dial Transplant 9: 309-312, 1994.

5. Sanfilippo F, Croker BP and Bollinger RR: Fate of four cadaveric donor renal allografts with mesangial IgA deposits. Transplantation 33: 370-376, 1982.

6. Koselj M, Rott T, Vizjak A and Kveder R: IgA nephropathy as a donor-transmitted disease in renal transplant recipients. Transplant Proc 23: 2643-2646, 1991.

7. Shiraishi S, Tomoda K, Matsumoto A, Kyomoto R and Yamashita T: Investigation of the local provocation test to PPP and IgA nephritis. Acta Otolaryngol Suppl 523: 178-181, 1996.

8. Yamabe $\mathrm{H}$, Osawa $\mathrm{H}$, Inuma $\mathrm{H}$, et al: Deterioration of urinary findings after tonsil stimulation in patients with IgA nephropathy. Acta Otolaryngol Suppl 523: 169-171, 1996.

9. Pozzi C, Andrulli S, Del Vecchio L, et al: Corticosteroid effectiveness in IgA nephropathy: long term results of a randomized, controlled trial. J Am Soc Nephrol 15: 157-163, 2004.

10. Barratt J and Feehally J: Treatment of IgA nephropathy. Kidney Int 69: 1934-1938, 2006.

11. Feehally J,Barratt J, Coppo R, Cook T and Roberts I: International IgA Nephropathy Network: International IgA nephropathy network clinico-pathological classification of IgA nephropathy. Contrib Nephrol 157: 13-18, 2007.

12. Working Group of the International IgA Nephropathy Network and the Renal Pathology Society; Cattran DC, Coppo R, Cook HT, et al: The Oxford classification of $\operatorname{IgA}$ nephropathy: rationale, clinicopathological correlations, and classification. Kidney Int 76: 534-545, 2009.

13. Working Group of the International IgA Nephropathy Network and the Renal Pathology Society, Roberts IS, Cook HT, Troyanov S, et al: The Oxford classification of IgA nephropathy: pathology definitions, correlations and reproducibility. Kidney Int 76: 546-556, 2009.

14. Yoshida M, Hatano N, Nishiumi S, Irino Y, Izumi Y, Takenawa T and Azuma T: Diagnosis of gastroenterological diseases by metabolome analysis using gas chromatography-mass spectrometry. J Gastroenterol 47: 9-20, 2012.

15. Tomosugi N, Kawabata H, Wakatabe R, Higuchi M, Yamaya H, Umehara $\mathrm{H}$ and Ishikawa I: Detection of serum hepcidin in renal failure and inflammation by using ProteinChip System. Blood 108: 1381-1387, 2006.

16. Kanmura S, Uto H, Kusumoto K, et al: Early diagnostic potential for hepatocellular carcinoma using the SELDI ProteinChip system. Hepatology 45: 948-956, 2007.

17. Kanmura S, Uto H, Sato Y, et al: The complement component $\mathrm{C} 3 \mathrm{a}$ fragment is a potential biomarker for hepatitis $\mathrm{C}$ virus-related hepatocellular carcinoma. J Gastroenterol 45: 459-467, 2010.

18. Schägger H: Tricine-SDS-PAGE. Nat Protoc 1: 16-22, 2006. 
19. Abou-Ragheb HH, Williams AJ, Brown CB and Milford-Ward A Plasma levels of the anaphylatoxins $\mathrm{C} 3 \mathrm{a}$ and $\mathrm{C} 4 \mathrm{a}$ in patients with IgA nephropathy/Henoch-Schönlein nephritis. Nephron 62: 22-26, 1992.

20. Wyatt RJ, Kanayama Y, Julian BA, Negoro N, Sugimoto S, Hudson EC and Curd JG: Complement activation in IgA nephropathy. Kidney Int 31: 1019-1023, 1987.

21. Matsuda M, Shikata K, Wada J, Sugimoto H, Shikata Y, Kawasaki $\mathrm{T}$ and Makino $\mathrm{H}$ : Deposition of mannan binding protein and mannan binding protein-mediated complement activation in the glomeruli of patients with $\operatorname{Ig} \mathrm{A}$ nephropathy. Nephron 80: 408-413, 1998.

22. Endo M, Ohi H, Ohsawa I, Fujita T, Matsushita M and Fujita T: Glomerular deposition of mannose-binding lectin (MBL) indicates a novel mechanism of complement activation in IgA nephropathy. Nephrol Dial Transplant 13: 1984-1990, 1998.
23. Espinosa M, Ortega R, Gomez-Carrasco JM, Lopez-Rubio F, Lopez-Andreu M, Lopez-Oliva MO and Aljama P: Mesangial C4d deposition: a new prognostic factor in IgA nephropathy. Nephrol Dial Transplant 24: 886-891, 2009.

24. Roos A, Rastaldi MP, Calvaresi N, et al: Glomerular activation of the lectin pathway of complement in $\operatorname{IgA}$ nephropathy is associated with more severe renal disease. J Am Soc Nephrol 17: 1724-1734, 2006

25. Pfeifer PH, Kawahara MS and Hugli TE: Possible mechanism for in vitro complement activation in blood and plasma samples: futhan/EDTA controls in vitro complement activation. Clin Chem 45: 1190-1199, 1999.

26. Morgan E, Varro R, Sepulveda H, et al: Cytometric bead array: a multiplexed assay platform with applications in various areas of biology. Clin Immunol 110: 252-266, 2004. 